\title{
Relationship between Polymerization Shrinkage of Matrix-Monomers and Marginal Leakage of Composite Resins
}

\author{
Yoshiaki TANI*, Katsumi SUZUKI**, Toshihiro HAMADA** and Shigeki YUASA** \\ *Department of Dental Materials, Research Center for Medical Polymers and Biomaterials, Kyoto Uni- \\ versity, Kyoto 606, Japan \\ **Fujisawa Research Laboratory, Tokuyama Soda Co., Fujisawa, Kanagawa-ken 252, Japan
}

Reeeived on September 20, 1985

The purpose of the present investigation was to clarify the relationship between polymerization shrinkage of the matrix-monomer of the composite resins and marginal leakage. Eight matrix-monomers differing in polymerization shrinkage $(2.7$ to $11.4 \%$ ) were experimentally prepared. Experimental composite resins were made from these monomers filling with $0.2 \mu \mathrm{m}$ spherical silica particles with a constant volume of 54.5 percent. Standardized Class V cavities were prepared on the labial surface of freshly extracted bovine teeth. Before placement of each restoration, the cavities were conditioned and primed with an experimentally prepared bonding agent in which consisted of the Bis-GMA-TGDMA system.

The marginal leakage was evaluated by the scores depending on the depth of the dye penetration. As a result, an S-shaped curve of correlation showed a clear transition at the point of 7 percent of the polymerization shrinkage of the matrix-monomer.

Key words: Polymerization shrinkage, Marginal leakage, Composite resin

\section{INTRODUCTION}

The intimate marginal adaptation of composite resins is considered to be the most important requisite, and this is strongly influenced by polymerization shrinkage, thermal expansion or mechanical properties of the resins.

The highly loaded composite resins, developed recently have yielded good results on thermal expansion and mechanical properties. Consequently, little attention has been paid to the importance of the polymerization shrinkage.

Asmussen $^{1)}$ reported the relationship of wall-to-wall polymerization shrinkage of composites to their various components and the effects of diluent monomer on the contraction in composites based on Bis-GMA. Brauer et $\mathrm{al}^{2}{ }^{2}$ studied the marginal adaptation of Bis-GMA-based composites containing various diluents. Davidson et $\mathrm{al}^{3)}$ demonstrated the influence of contraction stresses, developed during the polymerization of composites, on adhesion to dentin.

The purpose of the present investigation was to clarify the relationship between polymerization shrinkage of the matrix-monomers of the composite resins and marginal leakage.

\section{MATERIALS AND METHODS}

Eight matrix-monomers differing in polymerization shrinkage (2.7 to $11.4 \%)$ were experimentally prepared as listed in Table 1.

The rate of polymerization shrinkage (SV) was calculated by the specific gravities of 
the monomer and the polymer using the following equation:

$$
\mathrm{Sv}=\frac{\frac{1}{\mathrm{dm}}-\frac{1}{\mathrm{dp}}}{\frac{1}{\mathrm{dm}}} \times 100(\%)
$$

where $\mathrm{dm}$ is the specific gravity of the monomer, and dp is the specific gravity of the polymer.

The specific gravities of the monomers were determined using a pycnometer at a constant temperature room of $20^{\circ} \mathrm{C}$, and those of the polymers were determined by measurement of the balancing point of a hydrometer in $\mathrm{KCI}$ solutions of varying concentrations

Table 1 Polymerization shrinkage of several monomer formulations

\begin{tabular}{|c|c|c|c|c|c|}
\hline \multirow[b]{2}{*}{ Sample No. } & \multirow[b]{2}{*}{ Monomer } & \multirow[b]{2}{*}{ Wt $\%$} & \multicolumn{2}{|c|}{ Specific gravity } & \multirow{2}{*}{$\begin{array}{l}\text { Polymerization } \\
\text { shrinkage }(\%)\end{array}$} \\
\hline & & & Monomer & Polymer & \\
\hline \multirow{2}{*}{ M-1 } & Bis-GMA & 50.2 & \multirow{2}{*}{1.169} & \multirow{2}{*}{1.200} & \multirow{2}{*}{2.7} \\
\hline & M-9G'1) & 49.8 & & & \\
\hline \multirow{3}{*}{ M-2 } & Bis-GMA & 51.0 & \multirow{3}{*}{1.170} & \multirow{3}{*}{1.218} & \multirow{3}{*}{3.9} \\
\hline & $9 G^{2)}$ & 16.0 & & & \\
\hline & M-9G & 33.0 & & & \\
\hline \multirow{3}{*}{ M-3 } & Bis-GMA & 51.1 & \multirow{3}{*}{1.163} & \multirow{3}{*}{1.225} & \multirow{3}{*}{5.1} \\
\hline & $9 G$ & 31.8 & & & \\
\hline & M-9G & 17.1 & & & \\
\hline \multirow{2}{*}{ M-4 } & Bis-GMA & 50.3 & \multirow{2}{*}{1.156} & \multirow[t]{2}{*}{1.227} & \multirow{2}{*}{5.8} \\
\hline & $9 G$ & 49.7 & & & \\
\hline \multirow{2}{*}{ M-5 } & $\mathrm{D}-2.6 \mathrm{E}^{3)}$ & 77.7 & \multirow{2}{*}{1.101} & \multirow{2}{*}{1.192} & \multirow{2}{*}{7.7} \\
\hline & $\mathrm{NPG}^{4)}$ & 22.3 & & & \\
\hline \multirow{2}{*}{ M-6 } & $\mathrm{D}-2.6 \mathrm{E}$ & 80.6 & \multirow{2}{*}{1.114} & \multirow{2}{*}{1.210} & \multirow{2}{*}{7.9} \\
\hline & $3 G^{2)}$ & 19.4 & & & \\
\hline \multirow{2}{*}{ M-7 } & Bis-GMA & 55.5 & \multirow{2}{*}{1.133} & \multirow{2}{*}{1.235} & \multirow{2}{*}{8.2} \\
\hline & $3 \mathrm{G}$ & 44.5 & & & \\
\hline \multirow{2}{*}{ M. 8} & Bis-GMA & 42.8 & \multirow{2}{*}{1.050} & \multirow{2}{*}{1.185} & 11.4 \\
\hline & NPG & 57.2 & & & \\
\hline
\end{tabular}

1) $\mathrm{CH}_{3} \mathrm{O}+\mathrm{CH}_{2} \mathrm{CH}_{2} \mathrm{O}+\frac{1}{9} \underset{0}{\mathrm{C}}-\stackrel{\mathrm{C}}{\mathrm{C}}=\mathrm{CH}_{3}$

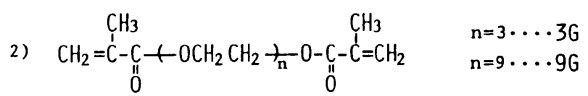

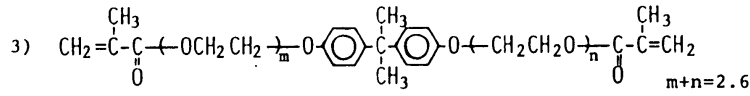

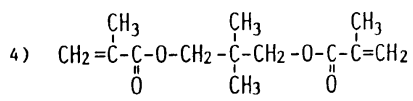


the above temperature.

Experimental composite resins were made of these monomers by loading with 0.2 $\mu \mathrm{m}$ spherical silica particles at a constant volume of 54.5 percent.

Standardized Class $\mathrm{V}$ round cavities, $3 \mathrm{~mm}$ in diameter and $2 \mathrm{~mm}$ in depth, were prepared on the labial surface of freshly extracted bovine teeth. Each cavity was conditioned with $37 \%$ phospholic acid solution for one minute. Before placement of the restoration, the cavities were primed with an experimentally prepared bonding agent consisting of the Bis-GMA-TGDMA system. Five teeth for each series were stored in water at $37^{\circ} \mathrm{C}$ for 24 hours. After careful finishing, the teeth were immersed in $0.1 \%$ aqueous solution of basic fuchsin under thermal cycling of sixty times between two water baths at $4^{\circ} \mathrm{C}$ and $60^{\circ} \mathrm{C}$.

After removal from the dye, the restored teeth were cut longitudinally and observed under a stereomicroscope. The marginal leakage was evaluated by the scores depending on the depth of the dye penetration as shown in Figure 1.

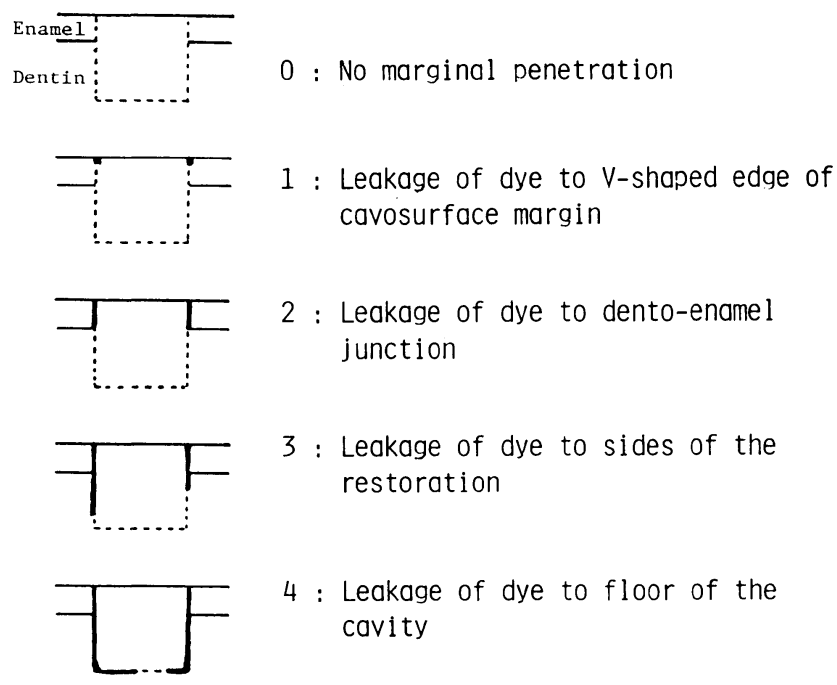

Fig. 1 Degree of marginal leakage

Table 2 Mean degree of marginal leakage of composites prepared with several monomer formulations

\begin{tabular}{ccc}
\hline Sample No. & $\begin{array}{c}\text { Polymerization } \\
\text { shrinkage }(\%)\end{array}$ & $\begin{array}{c}\text { Mean degree of } \\
\text { marginal leakage }\end{array}$ \\
\hline M-1 & 2.7 & 0 \\
M-2 & 3.9 & 0 \\
M-3 & 5.1 & 0 \\
M-4 & 5.8 & 0.2 \\
M-5 & 7.7 & 2.8 \\
M-6 & 7.9 & 3.0 \\
M-7 & 8.2 & 3.2 \\
M-8 & 11.4 & 3.0 \\
\hline
\end{tabular}




\section{RESULTS AND DISCUSSION}

The mean degree of marginal leakage of the composite resins prepared with several monomer formulations is shown in Table 2. The S-shaped curve of the correlation demonstrated a clear transition at the point of 7 percent of the polymerization shrinkage of the matrix-monomer. (Figure 2)

The relationship between polymerization shrinkage of matrix-monomer and marginal leakage affected by filler content is shown in Figure 3. Marginal adaptation improved

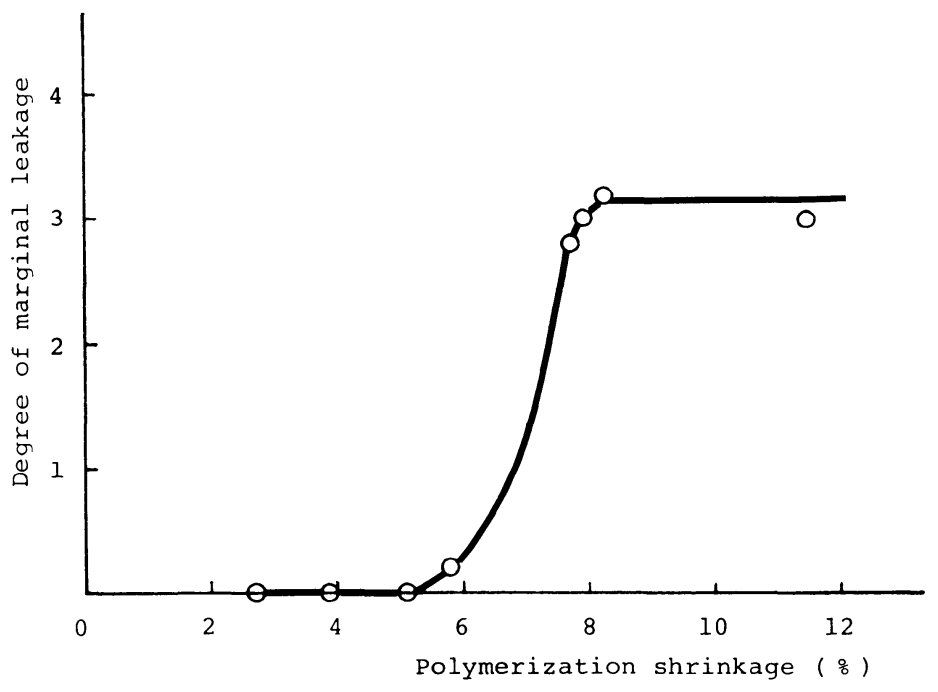

Fig. 2 Relationship between polymerization shrinkage of matrix-monomer and marginal leakage

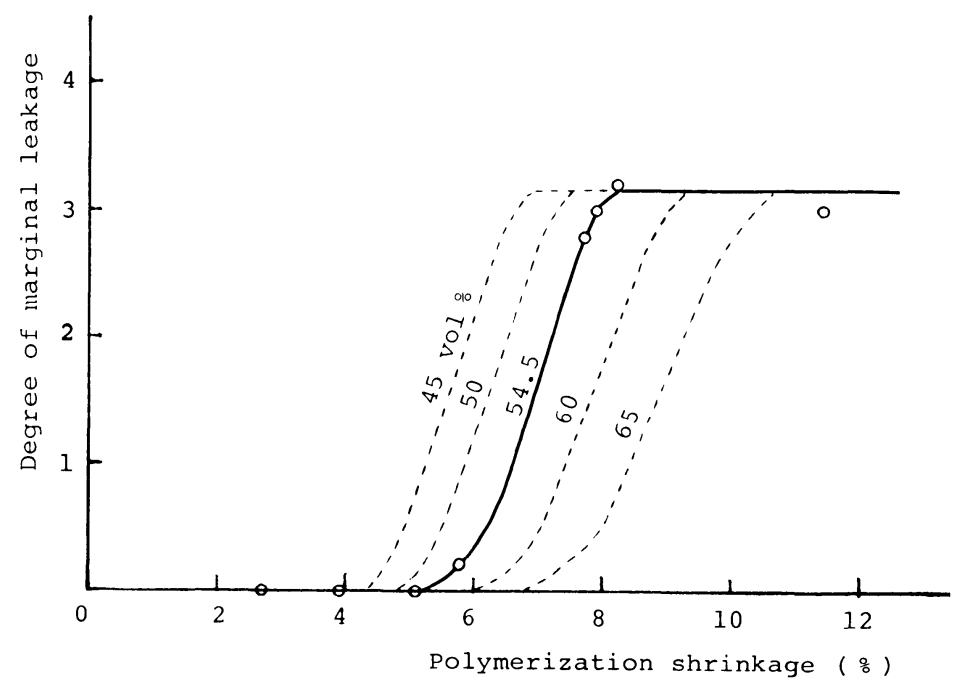

Fig. 3 Relationship between polymerization shrinkage of matrix-monomer and marginal leakage affected by filler contents 
Table 3 Mean degree of marginal leakage of commercially available composite resins

\begin{tabular}{lcc}
\hline \multicolumn{1}{c}{ Material } & Bonding agent & $\begin{array}{c}\text { Mean degree of } \\
\text { marginal leakage }\end{array}$ \\
\hline Adaptic Radiopaque & Bis-GMA-3G* & 0.8 \\
Clearfil F II & Bis-GMA-3G* & 0.6 \\
Superlux & Bis-GMA-3G* & 1.2 \\
Silar & Bis-GMA-3G* & 1.0 \\
\hline
\end{tabular}

* Experimentally made liquid resin

by increasing filler content.

The mean degree of marginal leakage of four commercially available composite resins is shown in Table 3. Clearfil F II, which contains the largest quantity of the inorganic filler among the four materials investigated, showed the least marginal leakage. In contrast, Superlux with the smallest quantity of the inorganic filler showed the greatest marginal leakage. From these data, it is considered that the increasing quantity of the filler compensated for the polymerization shrinkage of the matrix-monomer and improved the marginal adaptation of the composite resin.

\section{CONCLUSION}

1. An S-shaped curve of correlation showed a clear transition at the point of 7 percent of the polymerization shrinkage of the matrix-monomer.

2. It is considered that an increase in the filler content compensated for the polymerization shrinkage of the matrix-monomer and improved the marginal sealing property of the composite resin.

\section{ACKNOWLEDGEMENT}

This study was supported in part by a Grant-in-Aid for Special Project Research "Design of Multiphase Biomedical Materials" 1984, from the Ministry of Education, Science and Culture, Japan.

\section{REFERENCES}

1) Asmussen, E.: Composite restorative resins. Composition versus wall-to-wall polymerization contraction, Acta. Odont. Scand., 33: 337-344, 1975.

2) Brauer, G.M., Dulik, D.M., Hughes, H.N., Dermann, K. and Rupp, N.W.: Marginal adaptation of Bis-GMA-based composites containing various diluents. J. Dent. Res., 60: 1966-1971, 1981.

3) Davidson, C.L., de Gee, A.J. and Feilzer, A.: The competition between the composite-dentin bond strength and the polymerization contraction stress, J. Dent. Res., 63: 1396-1399, 1984. 
ジウム含有量の低い金パラ合金についてあ測定した。接 着耐久性を評価するため $4{ }^{\circ} \mathrm{C}$ と $60^{\circ} \mathrm{C}$ の水中熱サイクルを 最高2,000回まで行なってから引張り接着強さを測定し た。その結果各種表面処理のうち接着耐久性の向上に有 効であったのは加熱酸化処理, Sn 電析処理, シリコー ター処理などであった。また 2 種の接着材のうちでは
4-META-MMA-TBB 系レジンの方が接着耐久性がす ぐれていた。電解エッチングは被着面の粗造化には有効 であったが接着強さにはほとんど効果がなかった。とれ は電解エッチングによって最表目に貴金属成分がより多 く残留したためであると考えられた。

\section{純チタン・クラウンの臨床応用 \\ 井田一夫*, 谷嘉 明*, 堤 定美*, 都賀谷紀宏*, 南部敏之*, 末瀬一彦**, 川添堯彬**, 中村雅彦**, 和田弘毅**** \\ *京都大学医用高分子研究センター歯科材料疮用研究部門 $* *$ 大阪歯科大学補緅学第 2 講座 ***京都工芸瀻維大学工芸学部無機材料工学科 $\quad * * * *$ 和田精密蒾研株式会社}

純チタンの機械的性質は貴金属合金に近く，耐蝕性や 生体安全性むすぐれているので，新らしく開発された鋳 造方法により製作された純チタンのクラウン 100 コ以上 を 2 年間に亘り臨床的に使用したととろつぎの結果が得 られた。

純チタン・クラウンの適合性は銀-パラジウム 合金の
クラウンよりは幾分悪かったがニッケル・クロム合金の あのよりはすぐれていた。咬合調整など装着時の問題点 は各合金の間で差はなかった。純チタン・クラウンの装 着後の変色队咬耗は殆んどなく,プラークの付着につい ても合金間の差は認められなかった。

\section{複合レシン修復材のマトリックスモノマーの}

重合収縮率と辺縁封鎖性との関係

谷 嘉明*, 鈴木勝己**, 浜田敏裕**，湯浅茂樹**

*京都大学医用高分子研究センター蒾科材料応用研究部門 **徳山曹達侏藤沢研究所

マトリックスモノマーの重合収縮率と辺縁封鎖性との 関係を定量的に明らかにするととを目的として，以下の 実験をおこなった。異なる重合収縮率をむつマトリック スモノマーを 8 種類調製し, コンポジットレジンを武作 した。なお,フィラーとして $0.2 \mu \mathrm{m}$ の球状シリカを用 い，充埧率は $54.5 \mathrm{vol} \%$ に一定した。牛前歯唇面の円形 窝洞に試作コンポジットレジンを填塞した。 $37^{\circ} \mathrm{C}$ 水中に 24 時間浸漬保存後, 辺縁部を仕上げ研磨し， $0.1 \%$ フク シン水溶液中でサーマルサイクリング処理による色素浸
透試験をおこなった。修復菌の正中部を縦断，研磨し， その断面における色素の浸透度から辺縁封鎖性を評価し た。

その結果，マトリックスモノマーの重合収縮率が $7 \%$ 付近に変曲点をむつ S 字形の相関曲線が得られ, 重合 収縮率と辺縁封鎖性との間に明確な相関関係のあるとと をあきらかにした。また, フィラー充填率の増大がマト リックスモノマーの重合収縮を補償し，辺縁封鎖性が改 善されるととも示唆された。

多官能性モノマーの合成と物性飞ついて

(第 6 報）分子内にスピロ環を有するジメタクリレートの合成と物性について

川口稔, 福島忠男, 宮崎光治, 堀部 隆 福歯大, 理工

歯科用レジン村料の物性を改良するととを目的として，分子内にスピロ環を有するジメタクリレート3.9- 